〔第49回総会シンポジウム ディジタルX線画像の最適化一被曝線量の観点からー〕

6. I.I./TV-DR における被曝線量と物理特性の関係

小倉 敏 裕

(財)癌研究会附属病院

Key words: Digital radiography, II/TV system, Modulation transfer function, Digital Wiener spectrum, Detectabilities

\title{
RELATIONSHIP OF THE IMAGING PROPERTIES OF THE I.I./TV BASED DR SYSTEM FOR INCIDENT EXPOSURES.
}

\author{
TOSHIHIRO OGURA
}

Department of Radiology, Cancer Institute Hospital

\begin{abstract}
We investigated imaging properties of a $2048 \times 2048$ matrix I.I./TV based digital radiography (DR) system $(\mathrm{DR}-2000 \mathrm{H})$ for various incident exposures. It should be noted that the resolution property of the I.I./TV based DR system depends on the incident exposures, the level of signal current from the TV image pickup tube and also regarding the size of the iris in the TV lens. Digital Wiener spectra and the detectabilities of low-contrast objects were measured for different incident exposures. It can be clearly seen that the noise properties and detectabilities decreased with a decrease in the incident exposures. The digital Wiener spectra also seemed to depend on the specific combination 'of the MTF's of the optical lenses, the level of signal current from the TV image pickup tube and quantum mottle. We must pay attention to these parameters when acquiring clinical images and evaluating the imaging properties. Furthermore, because the sensitivity of this system is higher than that of screen-film system, an X-ray tube of $0.2-\mathrm{mm}$ focal spot is available routinely, the effect of geometric unsharpness can be reduced in practical clinical implementation; the resolving power of the DR system with $7^{\prime \prime}$-I.I. mode at a certain magnification factor are equivalent or even superior to the resolving power of screen-film system employed.
\end{abstract}

\section{1.はじめに}

I.I./TV システムを用いた DR では，X線検出効率が 高く被曝低減が可能である反面, 空間分解能が screen/ film system (以下 $\mathrm{S} / \mathrm{F}$ とする) に劣る. しかし, 最近登 場した I.I./TV 方式2048×2048マトリックス（以下 $2 \mathrm{k}$ とする) DR は, 二次蛍光面を $60 \mathrm{~mm} \phi$ に大口径化するな ど，空間分解能の改善が図られた I.I. を搭載している1 しかし, 装置の設定条件や入射線量によって, 解像特性 は同一インチモードにおいても，変化することが分かっ
た。同時にノイズ特性も変化する.ここでは, I.I./TV-DR についての線量と画像特性の関係について報告する.

\section{2. 方法}

\section{1 使用装置}

本研究で使用した I.I./TV 方式の DR 装置（DR-2000 $\mathrm{H}$, 日立メディコ) は, 出力口径 $60 \mathrm{~mm}$ の縮小比の小さ な12インチ I.I. (12，9，7 インチの 3 モード) と，2100 本 TVカメラ（1 インチ含浸型ダイオードガンサチコ ン）が搭載されている。光量を制御するアイリスは可変 
型で，口径制御の駆動は DR 装置内の CPU 管理のもと で行われている。出力映像信号は，アンプにより増幅さ れた後, A/D 変換器により $2 \mathrm{k}$, または, $1024 \times 1024$ マト リックス (以下 $1 \mathrm{k}$ とする) で10ビット（ディスプレイ時 は4096階調で表示）のディジタル信号に変換される。こ のとき, 最大映像信号電流は550 nA（ディジタル值 4095 に相当）に設定されている，また，専用のディストリビ ュータによって $100 \mathrm{~mm}$ ロールフィルムへの撮影も可能 である.

\section{2 被曝線量の測定}

$20 \mathrm{~cm}$ 厚のアクリル板を撮影し, S/F (HR 4/HRS お よびHR6/HRS, Fuji photo film co.), および, 各イ

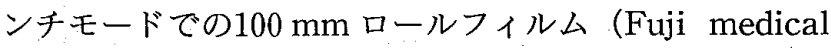
imaging film, type SF II）を用いたとき，濃度1.0とな る線量（ファントーム入射表面線量）を測定した。

\section{3 解像特性の測定}

DR 系に括ける固有な MTF として, 検出器自身の効 果（アナログ成分）とサンプリングアパーチャの効果を 含んだプリサンプリング MTF の概念が導入され ${ }^{2)}$ ，本 研究でもこのプリサンプリング MTF を測定した。測定 では, 副走查方向（TVカメラの走查線方向に垂直な方 向）に対してわずかに傾き（通常 2 度以内）をつけたス リットによる手法”をを用いて，“合成された”line spread function（以下，LSF）を作成する.この合成 LSF か ら，通常のMTF の計算と同じように計算し，プリサン プリング MTF を求めた ${ }^{4)}$.このとき, ベーリンググレア に相当する成分はカットし，LSF のすそ野部分は指数関 数で外挿した.スリットの撮影は, I.I.の入射面の中央部 に幅 $10 \mu \mathrm{m}$ のスリットを置き, 焦点-I.I. 入射面距離 80 $\mathrm{cm}$ 一定で, 管電圧 $80 \mathrm{kV}$ で撮影した. なお, 入出力特性 は, タイムスケール法によって求め5), ピクセル寸法(サ ンプリング間隔) は, I.I. の中心部において既知寸法の被 写体を撮影して実測した。

一方, 各拡大率における空間分解能の比較を $\mathrm{DR}-2 \mathrm{k}$, $100 \mathrm{~mm}$ ロールフィルム, S/F で行った ${ }^{6)}$. 解像力チャー 卜 (Nuc. Assoc.-Carle Plarle, N.Y-07-526 0.05 mm Pb $\mathrm{Nr}$ 67412）は，腹厚 $20 \mathrm{~cm}$ 被写体の中央を想定して，天 板上 $10 \mathrm{~cm}$ の位置に設置した. 焦点は通常使用している 小焦点 $(0.2 \mathrm{~mm})$ を使用した. $100 \mathrm{~mm}$ ロールフィルム や $\mathrm{S} / \mathrm{F}(\mathrm{HR} 6 / \mathrm{HRS})$ も同じ幾何学的条件で撮影した。ア イリス径を $28 \mathrm{~mm} \phi$ とし, 撮影条件は, $50 \mathrm{kV}, 20 \mathrm{~mA}$ で,ピクセル值が700前後となるよう撮影時間を調節し照 射した. $\mathrm{S} / \mathrm{F}$ は小焦点撮影を行うと照射時間が長くな り，実際の臨床撮影では運動ぼけとなって使用できない.
そのため大焦点 $(0.8 \mathrm{~mm})$ を使用した. DR の場合，表 示は 1000 本モニ夕を用い, $2 \mathrm{k}$ 画像の $1 / 4$ 領域表示で肉眼 による解像力を調べた。

\section{4 ノイズの測定法}

ここでは，入力から表示までのノイズ成分すべてを含 んだオーバーオール・ウィナースペクトル（以下WS と する)ではなく，1）X線量子モトル，2）I.I.の構造モト ル,3） TV カメラの電気ノイズ, 4）アンプのノイズ, 5) 量子化ノイズ等を含んだディジタルWSについて評価 を行った7).ディジタル WS は, A/D 変換後のピクセル 值から直接計算されるもので CRT やレーザープリンタ 一等のディスプレイ部の影響や画像処理の影響を含んで いない.また，量子化ノイズも一定である。撮影モード は 9 インチー定で行った. 実験では，アイリスサイズ一 定の状態で入射X線量を変化させたとき,ディジタル WS がどのように変化するかを調べた. 焦点-I.I. 間距離 $104.5 \mathrm{~cm}$, 管電压 $80 \mathrm{kV}$ で $2 \mathrm{~mm}$ の Cu を付加し, 一定の ゲインのもとで, X線を I.I. に照射し試料を作成した. I. I. 入射線量を変化させるために, 照射時間を変えた. WS の測定は，副走查方向について行い，I.I.の中心領域の $1024 \times 470$ ピクセルをノイズの計算に使用した.WS の計 算は, DR 装置から直接フロッピーに落し,フォーマット 変換を行い, FFT 法でパーソナルコンピューターで行っ た. I.I.のノンユニフォーミティー (不均一性) が存在す るために, バックグランドトレンド補正には, 多項式近 似曲線を用いた。

\section{5 低コントラスト被写体の検出能}

線量の変化による低コントラスト被写体の検出能の変 化を, ROC 解析によって調べた ${ }^{8,9)}$. あらかじめ $20 \mathrm{~cm}$ 厚 のアクリル板の中央に，バーガーファントム（直径と深 さの異なる各信昂が自由に配置できる自作の特性ファン トーム）を設置し，限界検出能を調べた。 その限界検出 領域の直径 $(0.4 \mathrm{~mm} \phi-5 \mathrm{~mm} \phi)$ と深さ ( $1 \mathrm{~mm}^{-} 5 \mathrm{~mm}$ ) が異なる被写体50個を選び，その信号50個と信号なし50 個をランダムに配列して，実験用のファントムとした。

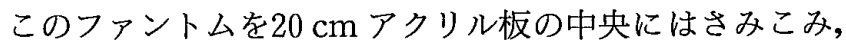
撮影を行った。 ROC 評洒は 5 段階評価で, 放射線技師 5 人によって行い, 1 画像当り合計5000観察結果より求め た. 撮影条件は全て $80 \mathrm{kV}$ である. 観察方法は, 実際の臨 床に使用しているときと同様, DR では CRT 観察で, 階 調設定は自由, 周波数処理なしとした. S/F の評価には シャーカステンを用いた。

\section{3. 結果}




\section{1 被曝 線 量}

$100 \mathrm{~mm}$ ロールフィルムを用いたときの濃度 1.0 を得 るのに必要な線量は，S/F（HR6/HRS）と比較した場 合, 12 インチモードで $\mathrm{S} / \mathrm{F}$ の約 $1 / 10,9$ インチモードで 約 $1 / 5,7$ インチモードで約 $1 / 3$ であった. S/F (HR4/

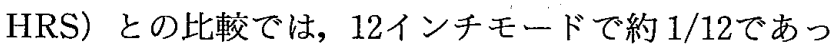
た. DR の場合，濃度1.0の規定がないので，現在 Table 1 に示した間接撮影（100 mm ロールフィルム）を基準 に, その 3 割減の線量で撮影を行っている.

\section{2 解 像 特性}

I.I. 中心部における実効ピクセル寸法は, $2 \mathrm{k} て ゙, 91 \mu \mathrm{m}$ (7インチ), $116 \mu \mathrm{m}$ ( 9 インチ)，および， $164 \mu \mathrm{m}$ (12 インチ) であった.

Fig. 1 に2k 各インチモードに扔ける主走查方向のプ リサンプリング MTF を示す.インチモードが小さくな る程, 良い解像特性を示した. しかし, 評価に際して, MTF 值がスリット像分布 (LSF) のピーク值に依存する ことが分かった，Fig. 2 に2k，7インチモードにおけ

Table 1 Comparison of incident exposures on the surface of a $20-\mathrm{cm}$ thick lucite phantom for screen-film and $100 \mathrm{~mm}$ roll-film systems.

\begin{tabular}{cc}
\hline \hline TECHNIQUE & INCIDENT DOSE \\
\hline SCREEN/FILM [HR4/HRS] & $250 \mathrm{mR}\left(64.5 \times 10^{-6} \mathrm{C} / \mathrm{Kg}\right)$ \\
SCREEN/FILM [HR6/HRS] & $194 \mathrm{mR}\left(50.1 \times 10^{-6} \mathrm{C} / \mathrm{Kg}\right)$ \\
$7^{\prime \prime}$ II MODE & $21 \mathrm{mR}\left(5.4 \times 10^{-6} \mathrm{C} / \mathrm{Kg}\right)$ \\
$9^{\prime \prime}$ II MODE & $43 \mathrm{mR}\left(11.1 \times 10^{-6} \mathrm{C} / \mathrm{Kg}\right)$ \\
$12^{\prime \prime}$ II MODE & $73 \mathrm{mR}\left(18.8 \times 10^{-6} \mathrm{C} / \mathrm{Kg}\right)$ \\
\hline
\end{tabular}

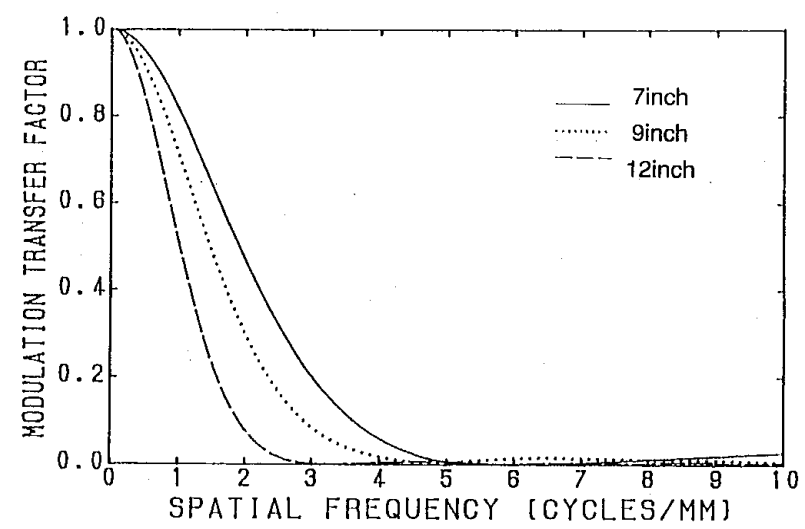

Fig. 1 Presampling MTFs of the I.I./TV based DR system at three I.I. modes for $2048 \times$ 2048 matrix in a direction parallel to the TV raster lines. (LSF peak value: 650 , iris diameter: $22.5 \mathrm{~mm}$ ).
る, LSF のピークのピクセル值が異なるプリサンプリン グ MTF を示す.アイリス径は33.5 mm $\phi$ 一定で, 線量 を変化させピクセル值を変えた，すなわち，線量を増や したとき大きなピクセル值となる．スリット像分布のピ 一クのピクセル值が小さくなると, プリサンプリング MTF が高くなった。

次に，ピクセル值を1100一定に保った状態で，アイリ ス径を変化させたときの解像力の変化を Fig. 3 に示す. アイリス径を絞ったときは線量を增やし，逆に広くした ときは線量を減じてピクセル值を1100亿保った。 アイリ ス径を絞るほどプリサンプリング MTF が高くなった。 これらの傾向を簡易的に解像力チャートを用いて実験し て確認したが同様の結果となった。

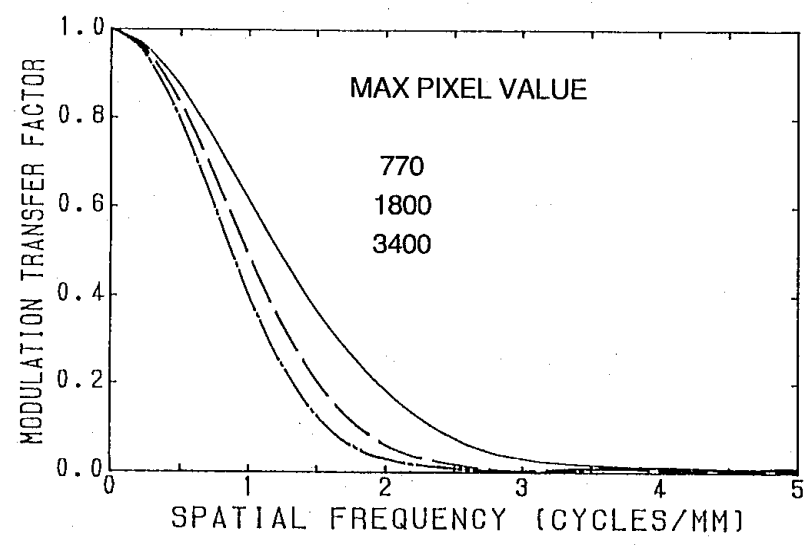

Fig. 2 Presampling MTFs of our DR system measured at the $7^{\prime \prime}-$ I.I. mode $(2048 \times 2048$ matrix), which demonstrates a dependency of MTF values on the peak value of the LSFs with the size of diaphragm $(33.5 \mathrm{~mm})$.

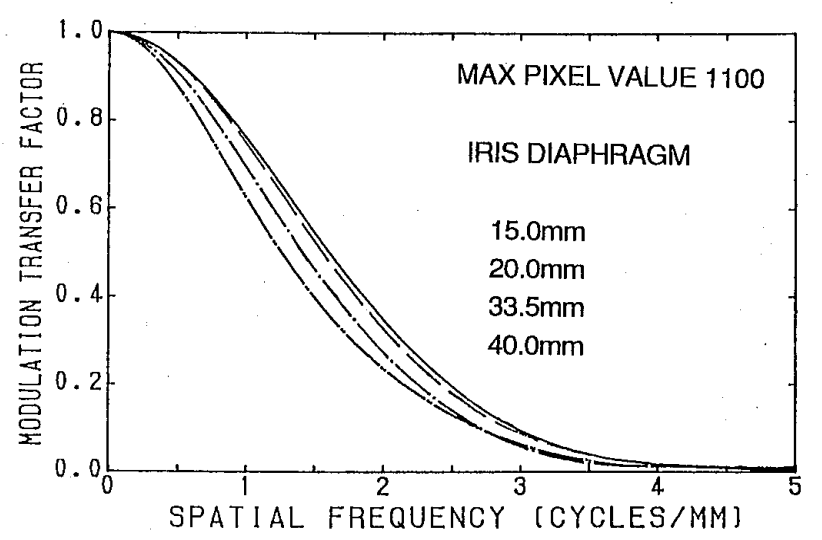

Fig. 3 Presampling MTFs measured at the $7^{\prime \prime}-$ I.I. mode ( $2048 \times 2048$ matrix), showing degradation as iris diameter in creases, for constant peak pixel value of 1100 in the LSFs. 


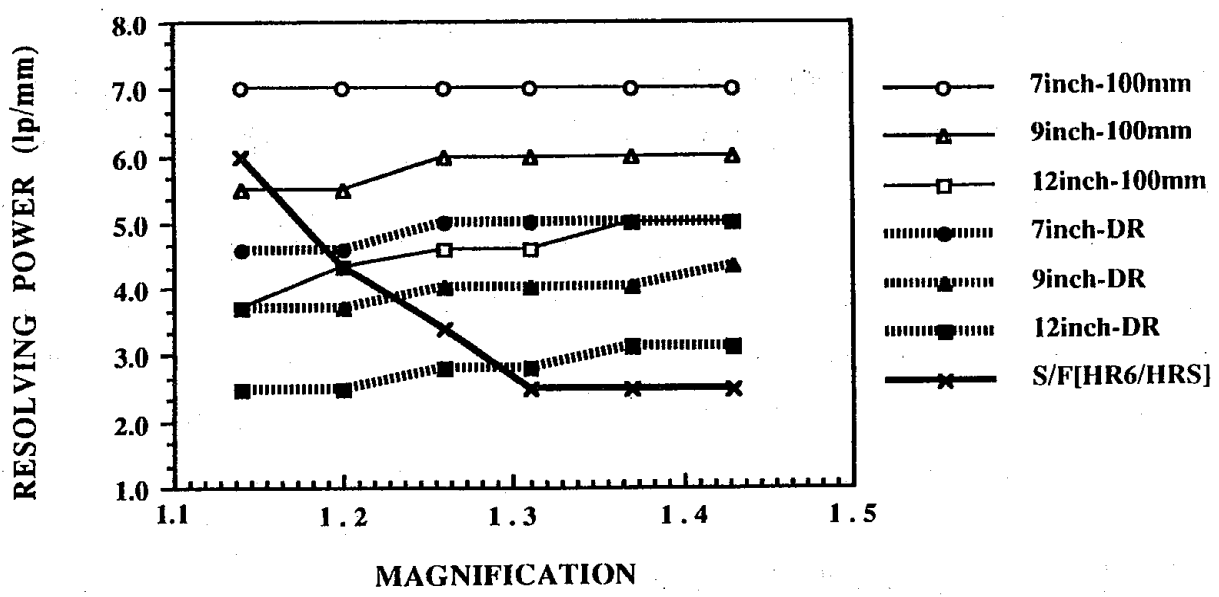

Fig. 4 Resolving powers as a function of magnification factor for the $100-\mathrm{mm}$ roll-film, the DR, and screen-film (HR6/HRS) systems.

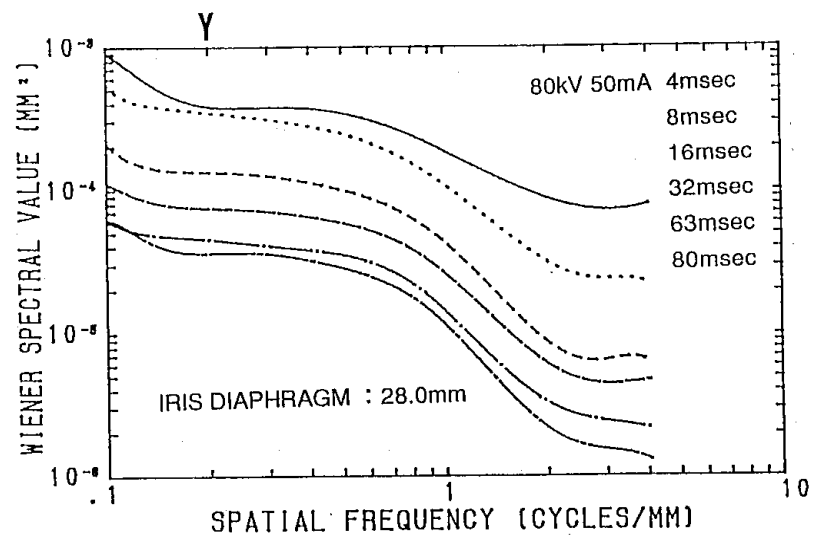

Fig. 5 Measured digital Wiener spectra for various incident exposures in a direction perpendicular to the TV raster lines. The image samples for noise measurements were exposed under the constant iris diaphragm $(28 \mathrm{~mm} \phi)$ with $9^{\prime \prime}$ I.I. mode.

各拡大率における，チャートを用いた解像力の結果を Fig. 4 に示す.S/F(HR6/HRS) は撮影線量の問題で, 大焦点を使用せざるを得ない. そのため，拡大率を上げ ると，焦点寸法に起因する幾何学的不鋭が大きくなり， 急激に解像力が低下した. $100 \mathrm{~mm}$ ロールフィルム7 イ ンチモードは，1.14〜1.43倍のすべての拡大率で7.0 lp/ $\mathrm{mm}$ が確認でき， $\mathrm{S} / \mathrm{F}$ の解像力より良い結果となった. DR-2k は，各インチモードで $100 \mathrm{~mm}$ ロールフィルムよ り劣った。しかし， S/F と比較した場合，7インチモー ドは，拡大率1.2倍以上になると $\mathrm{S} / \mathrm{F} よ り$ 良くなった。

\section{3 ノイズ特性}

Fig. 5 にアイリス径を一定 $(28 \mathrm{~mm} \phi)$ にし, I.I.への 入射線量を変えたときのWS を示す. 線量の増加に伴っ て，低周波数領域から高周波数領域にわたって，ノイズ

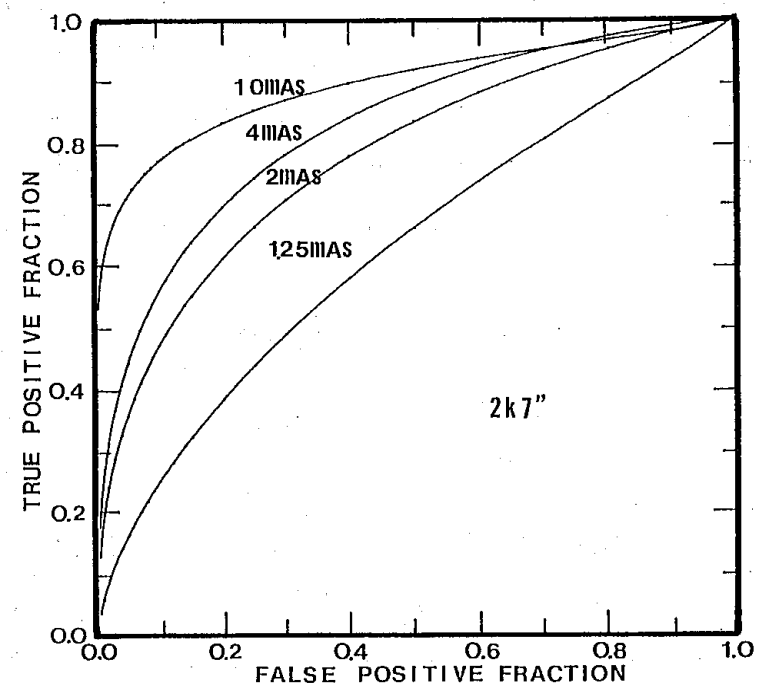

Fig. 6 Comparison of the receiver oparating characteristic curves for the detection of low contrast objects, which are investigated with the DR $(2048 \times 2048$ matrix, $7^{\prime \prime}$-I.I. mode) under various incident exposures.

特性の改善がみられた。

\section{4 低コントラスト被写体検出能}

Fig. 6 はDR-7インチで線量を変化させて撮影したと きの結果である。線量を下げると同時にアイリス径を大 きくピクセル值を等しくした，線量を少なくすると，検 出能は明らかに低下した。

\section{4. 考察}

Fig. 2 に示すように, MTF 值はスリット像分布 (LSF)のピーク值に依存し, 線量を増やすと解像特性が 悪くなる傾向がある，通常， $\mathrm{S} / \mathrm{F}$ 系のスリット法による MTF 解析においては, LSFの“すそ野”まで広い範囲 
にわたってスリット像分布を得るために，スリット像の ピークの値をできるだけ大きくとるように行ってきた。 そして,このとき, 得られた MTF の結果にスリット像 のピーク值の依存性がみられないことが “常識”であっ た ${ }^{10)}$. しかし, I.I./TV-DR では依存性がみられた の原因として, I.I. の線量の変化による解像特性の変化 と, 撮像管の信号電流の変化による解像特性の変化が考 えられる.前者については, $100 \mathrm{~mm}$ ロールフィルムを用 いて, I.I.の 2 次蛍光面のアナログ像の解像力を調べた. しかし，照射線量の異なる場合や，同一 $\mathrm{mAs}$ で管電流と 照射時間の組合せを変化させた場合でも, 解像力の変化 はみられなかった. したがって, 撮像管の信号電流が大 きくなることによって, MTF が低下するとい方る。撮像 管への入力光学像は, 入力フェースプレート上に電荷像 として形成され，その電子ビームによるスキャンによっ て電気信号に変換される. 入力光が過大になって信号電 流が大きくなったときには，像がにじみ，ブルーミング 現象が起きる.このブルーミングは, 空間分解能の低下 を招く一因と考えられる。この現象が起きるために倍数 露光の手法がとれない. また, 解像力は, Fig. 3 に示され るよう，撮像管の影響のみならず，アイリスの影響も受 けていることがわかった。この場合，アイリスを絞って 線量を増やすと解像特性が良くなる，本 DR システムは， レンズが $200 \mathrm{~mm}$ (F1.5), 二次レンズが50 mm（F0.65） の明るいものを使用している．このように口径の大きな レンズを使用しているため, 解像力のアイリス径低存性 は無視できない.アイリスを絞ることによる光学レンズ の解像特性の上昇は, 主に球面収差等が影響しているも のと考光られる。

12インチモードで, S/F の 1/10以下の線量で撮影して いるため, ルーチンに小焦点 $(0.2 \mathrm{~mm})$ 撮影が可能であ る.このため, 焦点寸法に起因する幾何学的不鋭が小さ くなり, 解像力の高い画像が得られる.X線検出器とし て,I.I./TV-DR の解像特性は S/F に劣るが, 小焦点拡大 撮影の技法が応用でき， S/F に匹敵する解像特性の有す る画像が得られる. 被写体厚が厚い場合, 被写体に密着 して撮影したとき, 拡大率が 1.2 程度となる。この様な被 写体に対し DR-2k，7インチモードの密着撮影の解像力 が，S/F の密着撮影と同等である。また，アンダーチュ ーブ方式の装置では，幾何学的不鋭の少ない画像を得る ために，被写体にできるかぎり $\mathrm{S} / \mathrm{F}$ を接近させるのが撮 影手技として常識である.しかし, 当 DR や $100 \mathrm{~mm}$ 口ー ルフィルムでは, 解像力に関して, 常に密着撮影する必 要はないとと言える. Fig. 4 に示すように, $100 \mathrm{~mm}$ ロー
ルフィルム 7 イチチードは, すべての拡大率で $\mathrm{S} / \mathrm{F}$ の 解像力より良い結果となったが，ディジタル化される前 のアナログ成分 (I.I. 自身) の解像力が大きく改善された ために，ディジタル化された画像も優れた解像特性を有 しているといえる.

アイリス径一定のもとで, 線量を増加させると, 全周 波数領域にわたってノイズ特性の改善がみられた。これ は，高周波数側（約 1.5 cycles/mm〜ナイキスト周波数） のノイズと低周波数側（約 1.5 cycles $/ \mathrm{mm}$ 以下）のノイ ズの改善が同時に起こっているためであることが別の実 験で分かっている ${ }^{12)}$. 高周波数側のノイズは, 線量を増す ことによってピクセル值が上昇し，MTF の劣下によっ て改善される.そのノイズの大きさは，カメラの信号電 流に依存し, 信号電流が大きくなるとディジタル WS 值 は小さくなる，一方，低周波数側のノイズは，主にX線 量子モトルの減少等により改善される。 また，アイリス 径による MTF の変化もノイズに影響している.

Fig. 6 亿示すように, 線量を少なくすると,ノイズの上 昇とともに，低コントラスト被写体検出能は明かに低下 する．DR 装置の場合, 線量はアイリス径の設定により $\mathrm{CR}$ と同様, 線量低減が可能であるが, むやみに線量を下 げるのは危険である，逆に，線量を多くすると検出能は 良くなる. しかし, 実際の臨床では線量を多くするため に大焦点 $(0.8 \mathrm{~mm})$ を使用しなければならず解像力が落 ちる. 小焦点 $(0.2 \mathrm{~mm})$ が使用でき，撮影タイマーが, 運動ボろの無い程度で切れるように，撮影条件の設定を 行うべきである。

\section{5.まと め}

1. 解像特性は,同一インチモードにおいてもアイリス 径とピクセル值がそれぞれ大きくなると低下することが わかった.このことは, I.I.への入射線量の増減により解 像特性が変化することを意味する。

a アイリス径を一定に保ち，入射線量を増すとピクセ ル值が上昇し解像特性が低下する。

b ピクセル值を一定に保つためにアイリス径を広くし， 入射線量を減ずると解像特性が低下する。

すなわち，高い解像特性の画像を得るためには，アイ リス径を絞り，低いピクセル值となるような線量で撮影 する。逆にあまり高い解像特性を必要としない場合，ア イリス径を広くすることによって被曝低隇が可能である.

2. 低線量撮影により，ルーチンに小焦点 $(0.2 \mathrm{~mm})$ 撮影が可能である。このため，小焦点拡大撮影の技法が 応用でき, $\mathrm{S} / \mathrm{F}$ に匹敵する解像特性の有する画像が得ら 
れる。

3.ノイズに関して, 線量の低減によって量子モトルが 増加し, ディジタルWS は上昇した。 そして, 同時に低 コントラスト被写体検出能の低下も顕著であった。また， ノイズ特性は, 解像特性と密接な関係があるため, アイ リス径や，ピクセル值によっても異なる。

このように, I.I./TV-DR の場合, 入射線量と解像特性 とノイズ特性の間には, 複雑な関係があり,これらの特 性を熟知したうえで撮影目的にあった DR 装置のパラメ 一タの設定, 線量, 撮影方法を決定する必要がある.

\section{謝辞}

共同研究者で, 終始ご指導頂いた岥阜大学工学部電子 情報工学科助教授藤田広志博士ならびに, 研究を進める にあたりご協力頂いた当院放射線部の皆様に厚くお礼申 し上げます。

最後に, 本研究の遂行にあたり技術的援助をしていた だいた侏日立メディコ技術研究所の諸氏に感謝致します。

\section{参考文献}

1）遠藤哲朗：高解像度リアルタイム DR 対応 12 寸高精 細 $\mathrm{X}$ 線イメージインテンシファイア V3733P の開 発., 映像情報（MEDICAL), 23(15), 854-858, (1991).

2) Fujita H., Doi K., and Giger ML. : Investigation of basic imaging properties in digital radiography. 6. MTFs of II/TV digital imaging systems., Med. Phys., 12, 713-720, (1985).

3) Fujita H., Tsai D.-Y., Itoh T., et al : IEEE Trans. Med. Imag., 11 (1), 34-39, (1992).
4）小倉敏裕, 藤田広志：新しい $2 \mathrm{~K} \times 2 \mathrm{~K}$ マトリクス II/ TV 方式のデジタルラジオグラフィの解像特性, Med. Imag. Tech., 9(5), 569-574, (1991).

5）藤田広志, 大西義隆, 坂本 清, 他：ディジタルラ ジオグラフィの画像評価〈 1 . 特性曲線〉, 日放技 学誌, 46, 1579-1592, (1990).

6）小倉敏裕, 岡村泰賢, 丸山雅一, 他: 高解像度 $\mathrm{X}$ 線 イメージインテンシファイアを用いた上部消化管診 断., 医用電子と生体工学, 30(4), 54-60, (1992).

7) Giger ML., Doi K., and Fujita H. Investigation of basic imaging properties in digital radiography. 7. Noise Wiener spectrum of II-TV digital systems., Med. Phys., 13(2), 131-138, (1986).

8) Metz CE. : ROC methodology in radiologic imaging, Invest. Radiol., 21, 720-733, (1986).

9) Ogura T., Masuda Y., Fujita H., et al: Technical and clinical evaluations of a $2048 \times 2048$-matrix digital radiography system for gastrointestinal examination., Proc.SPIE, 1443, 153-159, (1991).

10) Strubler K., Doi K., and Rossmann K. : Density dependence of the line spread function of radiographic screen-film systems., Phys. Med. Biol., 18, 219-225, (1973).

11) Ogura T., Fujita H., and Tsai D.-Y.: Resolution properties of a $2048 \times 2048-$ matrix II-TV based digital radiography system., Med. Phys.（投稿中）

12）小倉敏裕, 藤田広志：新しい $I I / T V-2 \mathrm{k} \times 2 \mathrm{k}$ マト リクスディジタルラジオグラフィのノイズ特性., Med. Imag. Tech. (抄録), 10 (3),267-268, (1992). 